PRAVEENADAS JENNIFER

and

PORCHELVAN P.

\title{
An approach to assessment of post mining-induced seismic hazard in Kolar Gold Fields mines - a review
}

A common challenge faced in underground hardrock mines worldwide is post mining-induced seismicity, as the events have been quite disastrous, causing risk to the structures and lives. In the recent years, many of the worked out mining areas are slowly getting populated and in due course of time shall be posing environmental threat to the people residing above and to the surface structures like sudden void formations or sudden ground collapse becoming visible on the surface. Worked out or closed mines have most of the time shown existence of post mining-induced seismicity signatures. Some of the closed mines showing post mining induced seismicity in Korea, South Africa, Sweden and India are being discussed. Post mining induced seismicity observed in Kolar Gold Fields worked out mine still being felt since closure of deeper levels is discussed. As mining depth increases especially in hard rock mines, magnitude of stress increases, hence, the occurrence and severity of postmining induced seismicity also increases. The problem becomes more serious if proper fund allocation is not done to investigate these areas, may be due to the absence of economic interest once the mine site has been abandoned and in many cases, direct investigations inside the mines may not be possible due to stability problems or due to the ingress of water into the void spaces of the mining area.

Several approaches and techniques adopted by researcher's world over are being discussed in this paper, with a view to gaining insight into the techniques of evaluation of seismic hazard. Seismic vulnerability assessment should integrate the effects of all the seismic events occurring at different locations of mining area during mining and post mining, along with their uncertainties also being considered. Based on the recorded data and some of the derived parameters from previous years, an attempt should be made to evaluate the existing risk prone areas. The past records of induced seismicity due to mining should be used as a precursor for identification of impending future events and their expected probable locations of occurrence.

$\overline{\text { Blind peer reviews carried out }}$

Mrs. Praveena Das Jennifer, Research Scholar, CDMM and Dr. Porchelvan P., Senior Professor, SCE (School of Civil Engg.), Vellore Institute of Technology, Vellore, Tamil Nadu, India. Corresponding author e-mail: pravi.jenniferdas@gmail.com
The methods discussed here for assessment of seismic hazard are based on direct waveform and seismic source parameters, parameters from indirect waveform methods, frequency-magnitude relationship based, and frequency content analysis based. From the assessment it is found that the choice of method that can be used depends on the period of monitoring (short-term monitoring, intermediate-term or long-term monitoring) and the objective of the study required to be achieved, this varies on site-to-site basis. The main focus is to show the importance and need to install a micro seismic monitoring system for long term assessment of seismic risk especially in abandoned/worked out mines showing post mining-induced seismicity.

Keywords: Induced seismicity, underground mines, abandoned mine, post mining-induced seismicity, regular monitoring, seismic hazard assessment.

\subsection{Introduction}

$\mathrm{M}$ ine-induced seismicity occurs due to failure of rock mass owing to alteration/redistribution of the actual stresses within the mine. There are two types of seismicity observed in the mines: triggered seismicity and induced seismicity. Triggered seismicity occurs on faults caused due to changes in stress that are very small in comparison with the ambient stress on the fault, like in fluid injections. The stress changes that occur in relation to the local/prevalent stress levels in specific are termed as induced seismicity and are noticed during mining and post mining. The several reasons for excessive stress formation in rockmass in underground mines are due to gradual failure of supports, lack of adequate mine reclamation, presence of ingress water in the mine, sudden fracturing of rock, the method of mining that was adopted, the existence of geological planes of weakness such as joints, faults or fracture networks. As mining depth increases, magnitude of stress increases, hence, the occurrence and severity of mine seismicity also increases.

The adverse effect of mine seismicity such as fatalities, injuries, damage to equipment and economic losses from loss of production can be minimized only by predicting precisely the location and time of seismic events. Whenever a mine is being closed, long-term risk assessment and preparation of 
proper closure plans are an essential requirement in order to maintain proper public health and assessing the probable damage to the subsurface structures and surrounding areas.

In abandoned mines, geo-engineering issues exist of uncertainty and lack of knowledge on the variations of geological features, details on the location of voids in the underground sections and tunnels at various exploration levels. In seismically hazardous areas, where previous mine subsidence events were observed in abandoned mines, seismic monitoring is very much essential. The regular monitoring of ground deformations and rock fracturing activity will help to understand the changes in ground conditions with time and will help to identify regions of potential mine instabilities. The recorded seismic activity over a short span of time proves to be very useful in various practical applications such as classification and delineation of zones of seismically active areas, in focal mechanism studies, the current prevailing state of ground stress conditions and in the seismic potential of a fault in the area.

Mining-induced seismic events have been quite challenging as the events can sometimes be life threatening and can cause huge loss of property as well. The past seismic history of worked out mines in India shows some large visible ground subsidence events and recent sinkhole formations in the densely populated areas close to the mining area, causing serious social, economic and political concerns to the residents as well as district administration and state government.

The study presents a close review on the mining-induced seismicity along with the influencing seismological parameters observed world over and drawing special attention on mining induced seismicity noticed in the deepest mines in India during pre-closure and post-closure of mine. A detailed study on the various seismological parameters so obtained by making use of advanced monitoring systems to quantify seismic sources so that the current seismicity can be arrived at.

\subsection{Mining-induced seismic monitoring in underground mines}

According to Durrheim et al. (2006), seismic events could be classified into types as: natural seismic events of lower magnitude and human or anthropogenic seismic events directly observed as a result of activities like reservoir filling and emptying, injecting or extracting of fluids, manmade explosions, mining and flooding of mines. The seismic events related to mining in deep hardrock underground mines, were termed as mining related events: mining triggered (direct effect due to mining activity) and mining induced (indirect effect during mining and post mining activity) (Szydlowska, 2016). Seismicity is more prominently observed in hardrock mines, as hardrocks can store strain energy for a longer period and exhibit a characteristic feature to suddenly release the strain energy in a violent way on occurrence of any minor changes in state of equilibrium of stresses in the rockmass called as rockburst. These events send out vibrations in the surrounding in the form of seismic waves. Seismicity is the consequence of the spatial and temporal deformation that a rock undergoes culminating in an eventual failure (Scheepers, 1982; Urbancic, T.I., et al., 1996; Hudyma, 2004).

Most of the metal mines are hard rock mines. The seismicity of a mine depends on the level of mining activity taking place, the deeper the mining, the higher is the chances of increase in seismic activity resulting in increase in the potential damage the rockmass undergoes from within causing increase in the fatality number and overall reduction in production. The reasons for increase in the seismicity of the area may be because of various factors like: the type of mining operation carried out, the local tectonics prevalent and the geology. Underground mine seismicity, is a result of both the temporal and spatial deformations that a rock undergoes leading to a visible damage/failure.

The latest development is making use of digital high frequency data acquisition systems with higher dynamic range, has made monitoring of microseismic a lot more less complicated. Nowadays with the obtained seismic waveform records, it has been possible to make use of several techniques of analysis that can provide better understanding of the failure mechanism that has occurred including stress orientations and fracture studies, detail study on characteristics of the source, such as source strength, extent of slip, energy and stress release.

\subsection{Seismic hazard assessment methods adopted world over}

Seismicity has been a very common phenomenon noted worldwide in metalliferous mines especially in, coal mines, gold mines and potash mines. Mining induced seismicity (Woodward, 2015) has been noticed world over in deep underground hardrock mines namely: Australia, China, Poland, Canada India, South Africa and Sweden. Some of the essential seismic parameters used for assessing a seismic hazard, shall be discussed in detail.

\subsection{Seismic Hazard Assessment Parameters}

A seismic event is described as inelastic deformations occurring suddenly within a rockmass and can be routinely computed in terms of its location, moment magnitude and seismic energy radiated (Srinivasan, 2015). The quantitative description of an event is based on definite characteristics like location, time and a minimum of two independent seismic source parameters like seismic energy, seismic moment, source size (Mendecki et al., 1999). Further Hudyma (2008) states that the quantitative components related to a seismic event can help in characterizing of one event and a population of events.

The seismic source parameters help in quantitatively assessing and defining a seismic hazard. Seismic source parameters are computed from basic information obtained 
from a seismic event, define the intensity and impact of individual seismic events and that of seismic event cloud. The potential of a seismic events depends on a number of its individual source parameters.

\subsection{Seismic Hazard Assessment Techniques}

Seismic hazard evaluation in mines has always been an area of research for assessment and prediction of rock failures. The universal procedure adopted in evaluating the seismic hazard of a region includes the determination of volumes that produce seismicity and estimating the return time of seismic events with varying magnitudes (Mendecki et al., 1999). Yet, a universal acceptance in quantification of seismic hazard on the defined scale has still not been developed. The study of mine induced seismicity and its application on predicting potential zones of failure and delineating the weak zones has been the state of active research where virgin state of the earth's stress is disturbed by the excavation of rockmass (Mendecki et al., 2010; Shen et al., 2013).

A number of techniques are available for evaluation of seismic hazard especially for underground mines (van Aswegen, 2005). The choice of techniques depends on the duration of monitoring and the objective required to be fulfilled. Mine Seismic hazard can be observed and evaluated over short-term, intermediate-term and long-term. Short-term observations would be useful for understanding response in strata and necessary inputs for adequate hazard prevention measures. Short-term hazard estimation is carried out to detect rockmass conditions possibly leading to large, visible and damage causing seismic events. Mid-term is for monitoring of strata behaviour as the mining activity progresses and develops to deeper levels, while the long-term is useful for day-to-day monitoring of the events, diurnal variation, continuous support to mining operations and study of overall behaviour of rockmass over a long period of the life of the mine. Mid-term monitoring of seismic hazard is done monthly, studying the variations in seismic source parameters and to finally identify the hazardous areas likely to experience events of higher magnitudes (van Aswegen, 2005).

Monitoring of seismic hazard should be done on longterm basis wherein throughout the mine, features of mining and geology parameters are to be considered. It gives the numerical probability of an event of a specified size, or it can give the probable arrival period for an event of a certain size (Kijko, 1997). Assessment of long-term monitoring of seismic hazard is estimated using numerical models (van Aswegen, 2005) that have been calibrated with reference to past mining seismic responses.

\subsubsection{Method based on waveform and seismic source parameters}

Using waveform techniques require seismograms with less scattering, noise and attenuation. Location of the seismic sensors should be chosen to surround the area of monitoring interest adequately so as to be able to sense the radiations from the subsurface seismic source. This technique is preferable for time constrained, low population data. But, such limitation of number of events based on time window might affect the accuracy and introduce ambiguity in determining source parameters.

Several approaches are available that bring out more useful and dependable results when the number of seismic events recorded are significant. The source parameters like, phase picking, event magnitude, time history of magnitude, event depth and distance, frequency spectrum analysis, $\mathrm{p}$ wave s-wave energy ratio and drop in stress are applied for source parameter analysis. The seismic source mechanism way of approach can be used when compared to waveform means of arriving at seismic source parameters, they are applicable to large amounts of seismic data.

The calculation of seismic energy both the release rate and stored rate can also be done using finite element based modelling Mitri et al. (1999) and inferred that they are the consequences of mining activities and useful in identification of potential zones of strain burst. Beer (2000) has developed an algorithm (Soothsay) for calculating larger mine induced seismic events from a deep gold mine and also developed a pattern recognition programming algorithm (indicator) for illustrating the seismic response to various mining activities to show the behaviour of rockmass affected due to mining using the induced seismic events.

Various indirect waveform methods and the different parameters used to quantitatively assess the hazard and the type of classification based on the methods are listed out as in Table 1.

\subsubsection{Method based on frequency-magnitude relations}

A seismic activity can be described quantitatively in terms of seismic activity rate, $\lambda$, Gutenberg-Richter $b$ value and the maximum magnitude, $X_{\max }$, that have occurred during the period ( $\mathrm{T}$ ) of monitoring. The seismic activity is a scale of measure used to rate the total of events with particular magnitude greater than a specified minimum magnitude value. The $b$-value from Gutenberg-Richter relation is used as an indicative value of the volume of damage or weakening of rockmass associated with the seismic event (Kijko and Funk, 1994).

The slope of frequency-magnitude relation developed by Gutenberg-Richter (Kijko, 1997) is an indicator of mechanism of seismic source. Seismic activities related to fault-slip show $b$-value very low of values less than 0.8 . Whereas stress change seismicity $b$-value is high ranging from 1.2 up to 1.5.

\subsubsection{Method based on frequency content analysis}

Frequency of seismic signals are important factors of seismic analysis as they carry a lot of information on the nature and size of the seismic events, the source size and its behaviour. While natural events like earthquake essentially 
TABLE 1: METHODS IDENTIFIED TO ASSESS SEISMIC HAZARD BASED ON THE DIFFERENT PARAMETERS

\begin{tabular}{|c|c|c|c|c|}
\hline & $\begin{array}{l}\text { Method used for assessment } \\
\text { of seismic hazard }\end{array}$ & Parameters used & Classification type & Reference \\
\hline 1 & $\begin{array}{l}\text { Excess Shear Stress (ESS)- } \\
\text { (when seismic records are } \\
\text { not available) }\end{array}$ & Shear stress, distance along fault, & $\begin{array}{l}\text { Regions of static shear stress, } \\
\text { dynamic shear strength along } \\
\text { a slipping fault }\end{array}$ & Ryder, 1988 \\
\hline 2 & $\begin{array}{l}\text { Volume Excess Shear Stress } \\
\text { (VESS)- (when seismic } \\
\text { records are not available) }\end{array}$ & $\begin{array}{l}\text { Slip on discontinuities, seismic } \\
\text { moment }\end{array}$ & Magnitude based classification & $\begin{array}{l}\text { Spottiswoode, } \\
1990\end{array}$ \\
\hline 3 & $\begin{array}{l}\text { Energy Release Rate (ERR)- } \\
\text { (when seismic records are } \\
\text { not available) }\end{array}$ & $\begin{array}{l}\text { Energy Release Rate, number of } \\
\text { seismic events }\end{array}$ & $\begin{array}{l}\text { Negligible, slight, moderate, } \\
\text { severe and extreme conditions }\end{array}$ & Hedley, 1992 \\
\hline 4 & $\begin{array}{l}\text { Departure indexing method } \\
\text { (DI) }\end{array}$ & $\begin{array}{l}\text { turbulence in seismic and static } \\
\text { parameters prior to the event like- } \\
\text { seismic energy of P-and S-wave, } \\
\text { apparent volume, seismic moment, } \\
\text { seismic radius, b-value, corner } \\
\text { frequency of P- and S-wave, and } \\
\text { static stress drop }\end{array}$ & $\begin{array}{l}\text { rock burst hazard indication } \\
\text { exceeds a critical value - } \\
\text { seismic event imminent }\end{array}$ & $\begin{array}{l}\text { Poplawski, } \\
1997\end{array}$ \\
\hline 5 & $\begin{array}{l}\text { Local Energy Release } \\
\text { Density (LERD) }\end{array}$ & loading system stiffness & $\begin{array}{l}\text { most likely location of } \\
\text { seismic event identified, and } \\
\text { anticipated failure as } \\
\text { progressive or violent }\end{array}$ & Wiles, 1998 \\
\hline 6 & $\begin{array}{l}\text { Cell evaluation method - } \\
\text { Modeled Groundwork } \\
(\mathrm{MGW})\end{array}$ & $\begin{array}{l}\text { 3D elastic boundary element model } \\
\text { - Probabilistic relation between } \\
\text { seismic event occurrence and event } \\
\text { strength }\end{array}$ & $\begin{array}{l}\text { event occurrence relations, } \\
\text { event strength estimates and } \\
\text { load-deformation state before } \\
\text { and after an event }\end{array}$ & $\begin{array}{l}\text { Beck and } \\
\text { Brady, } 2002\end{array}$ \\
\hline 7 & $\begin{array}{l}\text { Modified Mercalli Intensity } \\
\text { Scale }\end{array}$ & $\begin{array}{l}\text { average peak velocity or average } \\
\text { peak acceleration or both }\end{array}$ & $\begin{array}{l}\text { intensity value ranges from I } \\
\text { to XII with description (not } \\
\text { felt to total damage) }\end{array}$ & Bolt, 2003 \\
\hline 8 & Seismic Hazard Scale (SHS) & $\begin{array}{l}\text { rate of occurrence of events of a } \\
\text { certain magnitude,the power law } \\
\text { relation for mine seismicity, } \\
\text { maximum observed event magnitude }\end{array}$ & $\begin{array}{l}\text { Correlation as strong, weak } \\
\text { and no correlation events }\end{array}$ & Hudyma, 2004 \\
\hline 9 & $\begin{array}{l}\text { Coulomb stress change } \\
(\triangle \mathrm{CFF})\end{array}$ & $\begin{array}{l}\text { occurrence of each event and the } \\
\text { associated stress changes }\end{array}$ & $\begin{array}{l}\text { High and low stressed region } \\
\text { identification }\end{array}$ & $\begin{array}{l}\text { Orlecka-sikoraet } \\
\text { al., } 2009\end{array}$ \\
\hline
\end{tabular}

have longer propagation paths and low frequencies, the mineinduced events are confined with a few kilometers of distance in the three possible directions. This leads to transmission of frequency signals which are high in the proximity and intermediate range of frequencies at relatively longer distances. As the vibrations of the seismic events affect the surface structures, the frequency analysis provides wealth of information about seismic signal and material interaction.

Seismic hazards can also be analyzed, deterministically or probabilistically. In deterministic method, an assumed seismic scenario is taken and in probabilistic method, uncertainties in seismic event like location, time of incidence and size are being considered. In a seismic hazard study, the regional seismotectonics like the local faults, surface features, lineaments, shear zones, dykes joints, etc. should be considered. The past regional seismic data should be considered like the past seismic event locations, the size of the event, the occurrence rate of seismic events. The past seismicity of the area helps to understand the prevailing hazardous zones, choose a less hazard or no hazard zone for construction of new structures and in better seismic monitoring of hazardous zones.

A review of technique, various instrumentations deployed in various mines in the world and the various techniques adopted for monitoring the seismicity and hazard prediction 
TABLE 2: SEISMIC HAZARD ASSESSMENT METHOD ADOPTED IN MINES BASED ON PARAMETER AND TECHNIQUES USED - SOME EXAMPLES NOTED WORLD OVER

\begin{tabular}{|c|c|c|c|c|c|}
\hline & Country, Mine & parameters used & Equations/technique used & classification method & Reference \\
\hline 1 & $\begin{array}{l}\text { Australia, Junction } \\
\text { Gold Mine, } \\
\text { underground gold mine } \\
\text { - uniaxial and tria.lxial } \\
\text { accelerometers and } \\
\text { seismometers } \\
\text { (borehole) }\end{array}$ & $\begin{array}{l}\text { local magnitude, ratio } \\
\text { of S-wave: P-wave } \\
\text { energy, seismic } \\
\text { moment, radiated } \\
\text { energy and apparent } \\
\text { stress }\end{array}$ & $\begin{array}{l}\text { a subjective relative } \\
\text { hazard scale, b-value and } \\
\text { RHA techniques, seismic } \\
\text { source empirically from } \\
\text { seismic source parameters }\end{array}$ & $\begin{array}{l}\text { based on local magnitude } \\
\left(\mathrm{M}_{\mathrm{L}}\right): \mathrm{ML}<0.5-\text { small } \\
\text { events, } 0.5=\mathrm{ML}<1.0- \\
\text { moderate events and } \mathrm{M}_{\mathrm{L}}=1 \\
\text { - large events }\end{array}$ & $\begin{array}{l}\text { Uday } \\
\text { Singh, } 2002\end{array}$ \\
\hline 2 & $\begin{array}{l}\text { Poland, Legnica- } \\
\text { Glogow Copper } \\
\text { District (LGCD), } \\
\text { Copper mines - } \\
\text { uniaxial and triaxial } \\
\text { accelerometers (on } \\
\text { ground, both at the } \\
\text { base and on the crown) }\end{array}$ & $\begin{array}{l}\text { strong ground motion } \\
\text { parameters, PGA } \\
\text { values (PHA and PVA) }\end{array}$ & $\begin{array}{l}\text { Probabilistic seismic } \\
\text { hazard analysis (PSHA) } \\
\text { method. attenuation } \\
\text { relation for PGA values } \\
\text { (PHA and PVA) from } \\
\text { standard regression } \\
\text { analysis }\end{array}$ & $\begin{array}{l}\text { strong motion prediction } \\
\text { relations for the site, } \\
\text { identification of present and } \\
\text { future source zones of } \\
\text { seismic risks }\end{array}$ & $\begin{array}{l}\text { Lasocki } \\
\text { Stanislaw, } \\
\text { 2005, } 2008\end{array}$ \\
\hline 3 & $\begin{array}{l}\text { Canada, LaRonde } \\
\text { Mine, - uniaxial and } \\
\text { triaxial accelerometers } \\
\text { and surface geophone }\end{array}$ & $\begin{array}{l}\text { Apparent stress, } \\
\text { magnitude }\end{array}$ & $\begin{array}{l}\text { uses Nuttli magnitude } \\
\text { scale, relative apparent } \\
\text { stress ratio (ASR) }\end{array}$ & $\begin{array}{l}\text { A high ASR shows high } \\
\text { apparent stress of high local } \\
\text { stress conditions, and a low } \\
\text { ASR shows low local stress } \\
\text { conditions }\end{array}$ & $\begin{array}{l}\text { Laura } \\
\text { Brown, } \\
\text { 2015, } 2017\end{array}$ \\
\hline 4 & $\begin{array}{l}\text { South Africa, Central } \\
\text { Rand Mines, } \\
\text { underground gold mine }\end{array}$ & $\begin{array}{l}\text { moment magnitude, } \\
\text { seismic moment and } \\
\text { seismic energy, energy } \\
\text { of seismogram and the } \\
\text { maximum displacement } \\
\text { of phase }\end{array}$ & $\begin{array}{l}\text { Modified Mercalli } \\
\text { Intensity Scale (MMIS) } \\
\text { based on local magnitude } \\
\left(M_{L}\right)\end{array}$ & $\begin{array}{l}\text { for } \mathrm{M}_{\mathrm{L}} \text { from } 1 \text { to } 4 \text { - feeble } \\
\text { to moderate range } \\
\text { corresponded to MMIS of I } \\
\text { to } \mathrm{IV} \text { and for } \mathrm{M}_{\mathrm{L}} \text { from } 4.7 \\
\text { to } 5.3 \text { - moderate to strong } \\
\text { range, corresponded to } \\
\text { MMIS of IV to VI }\end{array}$ & $\begin{array}{l}\text { Sarfraz Ali, } \\
2016\end{array}$ \\
\hline 5 & $\begin{array}{l}\text { Sweden, Kiirunavaara, } \\
\text { underground iron ore } \\
\text { mine }\end{array}$ & $\begin{array}{l}\text { radiated energy, source } \\
\text { radii, apparent stress, } \\
\text { energy ratio and } \\
\text { apparent volume }\end{array}$ & $\begin{array}{l}\text { source parameters } \\
\text { estimated using spectral } \\
\text { analysis with a standard } \\
\text { Brune model }\end{array}$ & $\begin{array}{l}\text { events were classiûed as } \\
\text { shear/fault slip (FS) or non- } \\
\text { shear (NS) based on the Es/ } \\
\text { Ep ratio }\end{array}$ & $\begin{array}{l}\text { Emilia } \\
\text { Nordstrom, } \\
2017\end{array}$ \\
\hline 6 & $\begin{array}{l}\text { Australia, Renison } \\
\text { mine, underground tin } \\
\text { mine - triaxial } \\
\text { geophone (borehole) }\end{array}$ & $\begin{array}{l}\text { location, origin time, } \\
\text { seismic potency and } \\
\text { seismic energy, peak } \\
\text { ground velocity, } \\
\text { hypocentral distance, } \\
\text { source mechanism } \\
\text { parameters }\end{array}$ & $\begin{array}{l}\text { seismic hazard modelling- } \\
\text { Salamon-Linkov method, } \\
\text { ground motion hazard - } \\
\text { Monte Carlo simulation }\end{array}$ & $\begin{array}{l}\text { Seismic hazard as higher and } \\
\text { lower hazard area in space, } \\
\text { periods of lower and higher } \\
\text { hazard area with time. } \\
\text { Ground hazard as unlikely } \\
\text { and likelihood - likely, } \\
\text { possible, rare }\end{array}$ & $\begin{array}{l}\text { Malovichko } \\
\text { D A, } 2017\end{array}$ \\
\hline
\end{tabular}

efforts are listed in Table 2 .

Aswegen and Butler (1993) utilized the relations between the seismic energy released (E) and seismic moment (Mo) to detect the variations in rockmass behaviour in South Africa mines and observed a correlation between the structural features and the seismic parameters. Kijko and Funk (1994) studied the statistical parameters of induced seismicity such as the seismic event activity, the value of Gutenberg-Richter for South African mines when carrying out seismic hazard analysis for the mine.

Seismic hazard assessment has becomes very essential in some of the abandoned or worked out or closed mines showing post mining-induced seismicity over a period.

\subsection{Mining-induced seismicity in abandoned mines}

Underground mining activity all over the world has left us with various risks associated with abandoned mines, as these abandoned or dismissed or closed mines still are capable in sinkhole formations, subsidence, etc. Nowadays, abandoned mines are considered as environmental risk, requiring a longterm risk assessment on mine closure in order to protect the public residing above the mining areas from unforeseen 
occurrence of seismic events causing surface instability and to mitigate well in advance the extent of environmental damage to the surrounding areas. Some of the abandoned mines showing post mining induced seismicity in Korea, South Africa, Sweden and India are being discussed here.

\subsection{Korea}

In the abandoned arsenic (As) and heavy metal Kumho mine, located in Korea, a seismic investigation was carried out in 2005 to detect the possible deep mine induced seismicity with reference to the duffers that have been abandoned. The monitoring of induced seismicity was carried for six weeks using an array of digital REF TEK 130 recorders with seismometers and accelerometers spread over the entire mining area. The Kumho mine was closed since 2001. The software used was SNDP software (SYNAPSE Center for Science, 2006) for data processing and the 1D, 2D and 3D tools were used for graphics. The hypocenter of induced seismic events was identified as deep clouds of seismic events at depths of up to $1000 \mathrm{~m}$ from surface using seismic location programmes by Heiger least square fitting method. The events were identified as events generated from rock bursts and the displacements were found to have occurred along faults and fractures.

\subsection{SOUTH AFricA}

Mining was started in Witwatersrand basin, South Africa in the year 1886. From the year 1908, mining induced seismic events were reported to occur in Witwatersrand basin in South Africa and continuing to occur in $4000 \mathrm{~m}$ deep in some parts of the basin (Handley, 2013). The induced seismic events are occurring in active mining areas as well as in abandoned mining areas. The Central Rand Mines closure started in 1950s and the last operational mine was closed in 2008. With the closure of 100-year-old underground mines, it left behind large volume of excavated voids allowing the groundwater table to rise due to stoppage in dewatering process in the mines. Post mine closure, seismic event monitoring was conducted for a period about two and a half years from April 2010 to October 2012 (reported by Council of Geoscience in 2013) in and around the abandoned mines. The local magnitude $\left(\mathrm{M}_{\mathrm{L}}\right)$ of seismic events was found to be ranging from 0.2 to 3.4. The local magnitude $\left(\mathrm{M}_{\mathrm{L}}\right)$ corresponded to Modified Mercalli Intensity Scale (MMIS) of I to IV and described as events of feeble to moderate range.

\subsection{SWEDEN}

The Dannemora iron ore mine located in central Sweden, extending hundred meters below the surface. In 1992, production was stopped and in 2012 the production was restarted. Induced seismicity was monitored using four temporary 3 component seismometer sensor stations placed on the bedrock in close proximity to the mining area. Different methods were used in this investigation to characterize mine seismicity: picking of seismic events from recorded data using SEISAN waveform analysis tool, statistical analysis of activity rate of the seismicity over time from recorded data; spectral analysis using Code of Seismic Analysis to study the frequency content; magnitude analysis to study the different types of seismicity within the mine.

Microseismic events were categorized into two types: Type I as events occurring within the mining area and related directly to mining activity and Type II as events occurring on pre-existing geological zones of fractures and faults with higher magnitudes than Type I. Three types of mining induced events were identified: first type were events with low frequency and first emergent arrivals, events of long durations and third type events of high frequency (with first arrivals with long durations). The events with low-frequency were caused by reactivation of zones close to the fault due to mine activity and events within the mine were related directly to the mining. The high-frequency events and emergent events of long durations were direct causes of mine activity (Joanna Holmgren, 2015).

\subsection{India (Kolar Gold Fields - STUdy AREA)}

Geographically, the mining area identified is located in district of Kolar, Karnataka, India. Kolar Gold Fields (KGF) is situated at $12^{\circ} 57^{\prime}$ lattitude North and $78^{\circ} 16^{\prime}$ longitude, between $12.92 \mathrm{~N}-12.98 \mathrm{~N}$ and $78.24 \mathrm{E}-78.27 \mathrm{E}$, at $900 \mathrm{~m}$ altitude, lying at $100 \mathrm{~km}$ east of Bangalore city in South India.

Geologically, Kolar mining region lies in the schist belt of Kolar, Dharwar Craton of Indian southern peninsular. The 80 $\mathrm{km}$ long schist belt is in north-south orientation and $4 \mathrm{~km}$ wide along east-west. Located on the schist belt of Kolar are three mines: the Nundydroog Mine in the north, Champion Reef Mine in the center and Mysore Mine. The three major fault systems identified in this mining region are, the prominent Mysore North Fault, striking NW-SE right through the middle of the region and the other two identified faults are minor faults running sub parallel to MNF, Tennant Fault and Gifford Fault (Srinivasan et al., 2013; Praveena et al., 2016). The geology of area is shown in Fig.1.

KGF mines that produced gold are more than 130 years old and is the deepest mines with a mining depth of $3200 \mathrm{~m}$ in the country. As the resources depleted and grade of remaining ore body was considerably poor, mining in the deeper levels was discontinued in 1991. Thus, the entire Kolar Gold mines remain abandoned for more than 2 decades and accumulation of groundwater.

The abandoned gold mines has shown post mininginduced seismic history with uncertainty of future prevalent seismicity with respect to magnitudes and intensities of microseismic events. The population of KGF is around 3.0 lakh, covering the centrally placed township located close to the mined-out Champion Reef (abandoned mine now) and consists of concrete, masonry, steel surface structures of various types with low and high- rise buildings.

Site-specific mining-induced seismic parameters are very 


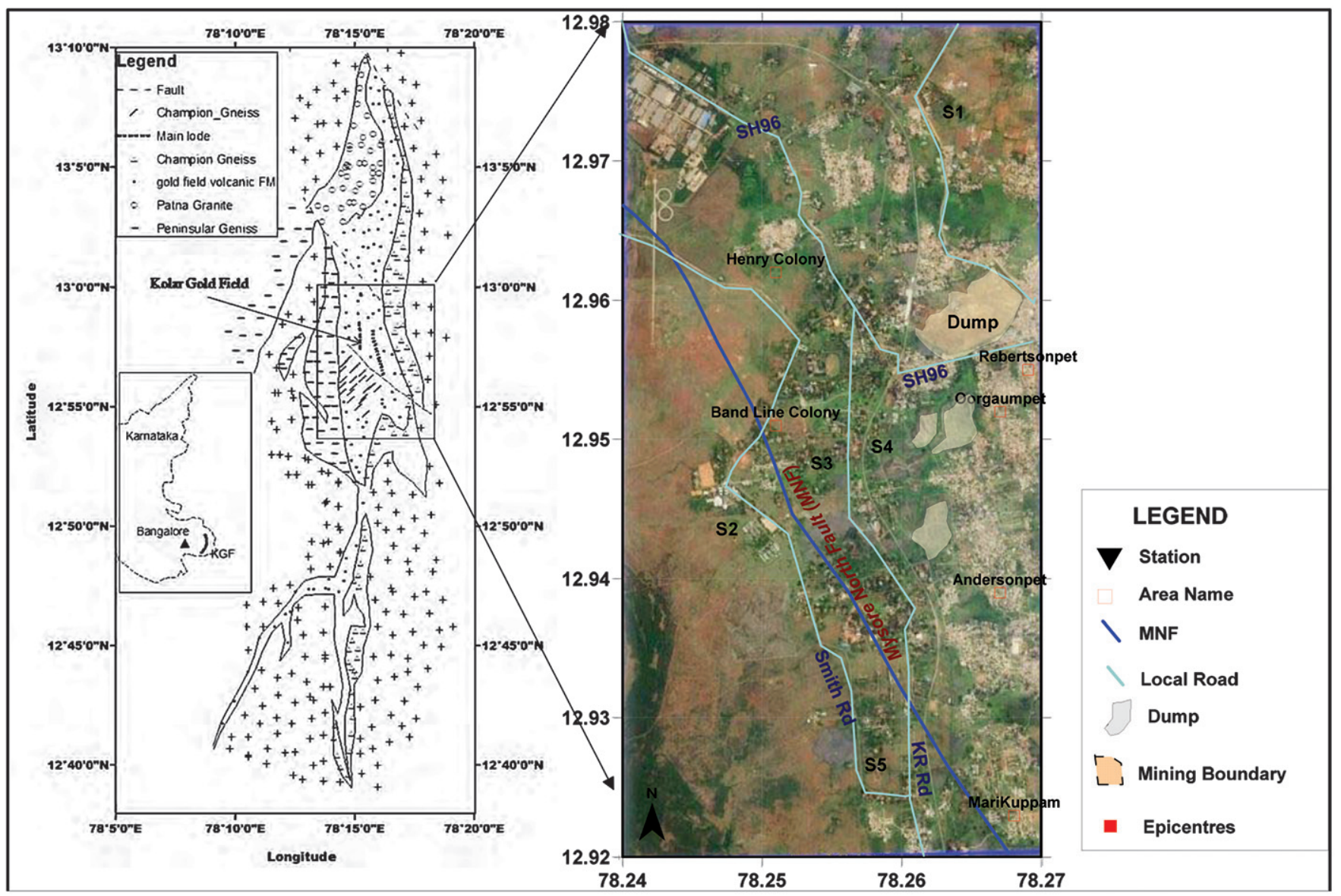

Fig.1: Geology map of Kolar Gold Fields (Srinivasan et al. 2013) and the Mysore North Fault

essential, without which there exists an uncertainty in the assessment of risk to the safety and stability of surface structures in future.

The Champion reef mine, the second deepest mine in the world has experienced fluid induced seismicity after the closure of mining operations following inundation. A series of major and medium seismic events were triggered at the Northern Folds and Glen Ore Shoot mining region (October 1991 - September 1992), microseismic activity during the second year began in October 1992 and was in continuous till September 1993 during which period, the rockbursts of both major and medium intensity, gradually shifted upwards horizontally and vertically. It was observed that the seismic events concentrated in between Champion reef mine dyke and the prominent MNF and also on either side of dyke and fault. The hypocentres of seismic events during the third year shifted upward towards shallow mine workings and old mine workings up to September 1994. A lull period in seismic activity was observed after September 1994 till June 1997 (Srinivasan et al., 2009). The 14-channel seismic geophone network system was in operation till 1998, and then the system was discontinued as it became obsolete. Seismic events recorded to have maximum magnitude range varying from -1.65 to 3.14 .
By 2000 , the mining activity was completely ceased. The seismic activity continued further and the mining area experienced areal-rockburst (phenomenon of one rockburst triggering a series of rockbursts in its surroundings) between 2004 and 2008. From 2005 onwards till 2018 (Praveena et al., 2016) the seismic monitoring was carried out using a strong motion accelerograph and a broadband seismometer installed at NIRM observatory in 2005 (Srinivasan et al., 2009). The seismic events recorded by the Strong Motion Accelerograph during the period (2006-2012) has been analysed. The time series of accelerograms of all events were subjected to baseline correction. The parameters of the events computed had maximum peak ground acceleration of $0.10042 \mathrm{~g}$, peak ground velocity of $1.03716 \mathrm{~cm} / \mathrm{secand}$ peak ground displacement of $0.0298 \mathrm{~cm}$. In most cases (958) out of 1158 the event predominant frequencies were around $25 \mathrm{~Hz}$. The magnitudes of these events were in the range of 0.21 to 3.9. An overview of the seismic monitoring systems used, and seismic activity observed along with the period of reference is being presented in Table 3 .

The overall number of seismic events year-wise using systematic seismic monitoring system is presented in Fig.2. During this period the maximum magnitude was 4.68 at a radial distance of $2 \mathrm{~km}$. Cluster of events were observed up to $2 \mathrm{~km}$ 
TABLE 3: OVERVIEW OF MONITORING SYSTEMS USED FOR DETECTION OF SEISMIC ACTIVITY OBSERVED ALONG WITH PERIOD OF REFERENCE

\begin{tabular}{|c|c|c|c|}
\hline $\begin{array}{l}\text { Seismic } \\
\text { monitoring period }\end{array}$ & Instrument used & Seismic activity & Reference \\
\hline 1978 to 1990 & \multirow{4}{*}{$\begin{array}{l}\text { regional multi-channel seismic } \\
\text { network was established in } \\
1978 \text {, consisting of } 14 \\
\text { Geophones - } 7 \text { surfaceand } 7 \\
\text { underground covering the entire } \\
\text { mining area }\end{array}$} & $\begin{array}{l}\text { Around } 10,000 \text { seismic events concentrated in the } \\
\text { vicinity of deep-level mine workings of the }\end{array}$ & $\begin{array}{l}\text { Krishnamurthy } 1980 \text {; } \\
\text { Subbaramu } 1985\end{array}$ \\
\hline $1991-1993$ & & Champion Reef and Nundydroog mines & \\
\hline \multirow[t]{2}{*}{$1994-1997$} & & $\begin{array}{l}\text { 1991, closure of deep mine workings, inundation } \\
\text { of water leading to fluid induced seismicity }\end{array}$ & \multirow{2}{*}{$\begin{array}{l}\text { Raju et al. 1991; } \\
\text { Srinivasan et al. } \\
\text { 1997, } 2000 \\
\text { Srinivasan et al. } 2000\end{array}$} \\
\hline & & Seismic activity was found to be very low & \\
\hline $1997-2004$ & $\begin{array}{l}3 \text { component seismometer - } \\
\text { GURLAP broad band system } \\
\text { (BBS). sensor-CMT } 40 \mathrm{~T} \text { and } \\
\text { a data acquisition unit } 72 \mathrm{~A}-07\end{array}$ & $\begin{array}{l}\text { Around } 800 \text { microseismic events recorded with } \\
\text { maximum local magnitude ranges varying from - } \\
1.65 \text { to } 3.14 \text {, occurring at shallow depths within } \\
1 \mathrm{~km} \text {. }\end{array}$ & $\begin{array}{l}\text { Srinivasan et al. } \\
\text { 2009, 2010, } \\
\text { 2012Malliga S } 2013\end{array}$ \\
\hline \multirow[t]{2}{*}{$\begin{array}{l}2005-2014 \\
2014-2018\end{array}$} & \multirow{2}{*}{$\begin{array}{l}3 \text { component Trillium } 240 \\
\text { sensors with Taurus digital } \\
\text { seismograph data acquisition } \\
\text { unit and a Strong Motion } \\
\text { Accelerograph }\end{array}$} & $\begin{array}{l}\text { Around } 2000 \text { seismic events with their epicentres } \\
\text { in and around the abandoned mining region. }\end{array}$ & $\begin{array}{l}\text { Srinivasan et al. } \\
\text { 2013, Praveena et al. } \\
2016\end{array}$ \\
\hline & & $\begin{array}{l}\text { Seismic monitoring still in progress with some } \\
\text { large visible ground subsidence events and recent } \\
\text { sinkhole formations }\end{array}$ & \\
\hline
\end{tabular}

radius with local magnitude varying between 0.5 to 1.5 .

From Fig.2, it is observed that the year 2006 has the highest recorded number of events with 816 events and the least number of events were recorded in the year 2014 with 18 events. There is an overall reduction in the events recorded, but still there certainly has been growing concern as the tremors are felt at irregular intervals leading to apprehension among civil community. The intensity of tremors felt are likely more when the source location of the seismic events become shallower.

Geologists and geophysicists of Geological Survey of India (Panduranga et al., 2009) had carried out geological, geophysical and geotechnical investigations for assessment of seismic hazard in KGF mines area. The Fig. 3 shows seismic

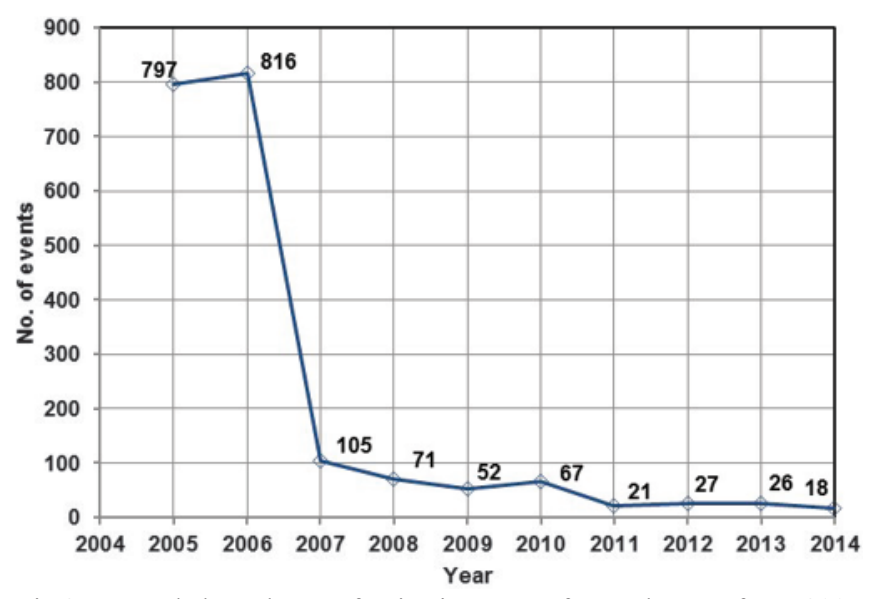

Fig.2: Recorded total no. of seismic events for each year from 2005 till 2014

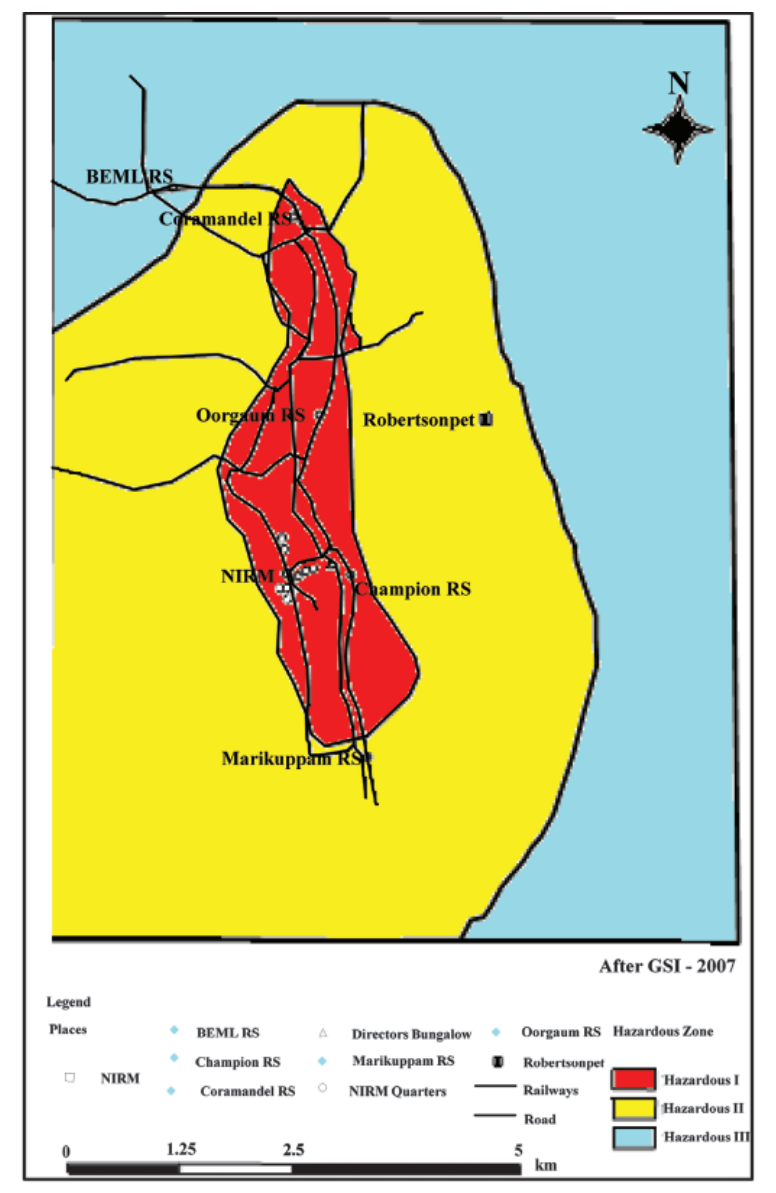

Fig.3: Seismic hazard map of Kolar Gold Fields (Panduranga et al., 2009) 
hazard map of Kolar Gold Fields. Their work has identified zones of vulnerability and mapped various zones in the mining area accordingly into three zones. Most hazardous directly above the mines with high frequency rockburst events with magnitude greater than 2.5 and indicating shear fracturing along major critically stressed structural weak zone/ faults and major discontinuities. Moderately hazardous along the periphery of the mines. The farther ones as less hazardous with low frequency rockburst events with magnitude less than 2.5 and indicating region with roof collapse/spalling wall/rock fall. This mapping was based on direct observations with geology and geotechnical measurement at select places correlated with the magnitude of seismic events.

The area was broadly classified into three hazard zones namely: high hazard, moderately hazard and low hazard regions.

\subsection{Discussion}

After the complete closure of the century old gold mines of KGF in 2000, the occurrence of seismic events of varying intensities were noticed periodically. Development of cracks in the buildings, sinking of ground at several locations above the mining areas regularly began to be the major concern for the people residing above and in zones close to the mining areas related to safety of property and life.

The seismicity was monitored using a single station recorder (Strong Motion Accelerograph) after the closer of mines, as the sophisticated 14 sensor seismic monitoring system became obsolete by then and could not be continued further. With the limitations of having a single station only the epicenters of events could be computed and the depth at which the seismic event takes place could not be arrived at accurately. It is not possible to get exact cause/mechanism of the event and its effect on the buildings which are just above the old mine workings. There arose a necessity to carry out scientific monitoring of seismic activity in the mining area by use of a well spread over network of sensors for identification of vulnerable zones and preparation of a local seismicity map.

The mine induced seismic hazard of area was last assessed and mapped in the year 2007. The hazard map of Kolar Gold Fields showed areas lying directly above the mines as most hazardous while the periphery ones with moderate hazard and the farther ones as less hazardous.

The seismicity pattern of Kolar Gold Fields (Fig.4), shows sudden increase in seismicity in some consecutive years as high as 900 to 1000 events (1970 and 2005) followed by low seismicity from 600 events in 1975 to 100 events in 1990, 67 events in 2010 and drops low to around only 18 events in 2014. The irregularity in events in each year, indicates firstly, the recurrence of seismic events. Secondly, the seismicity pattern shows, a high seismic event period followed by gradual decreasing low seismic event period. The chances of having a high event period may be expected in the coming years.

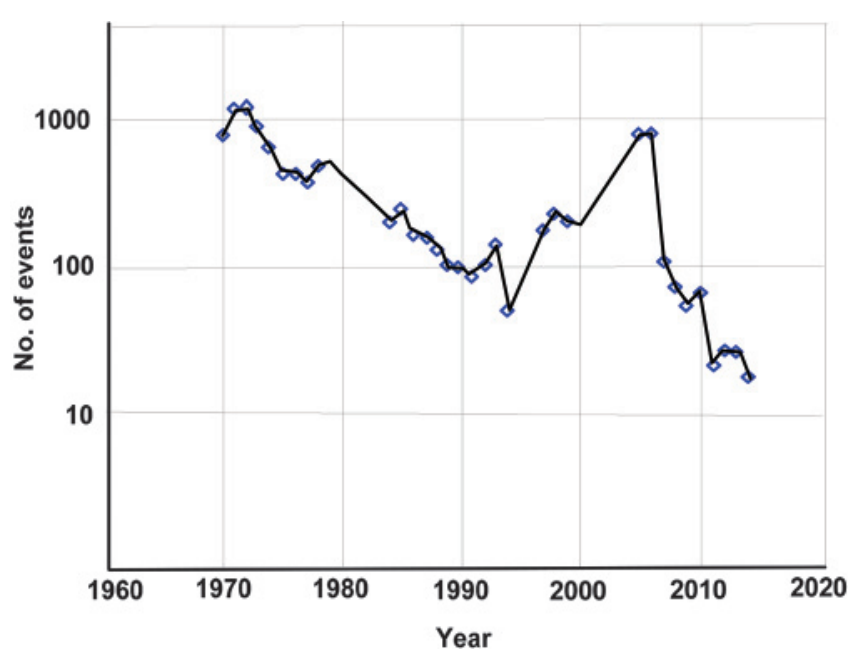

Fig.4: Seismicity pattern of Kolar Gold Fields (unpublished report of NIRM)

The case studies of Korea, South Africa and Sweden are referred to here in this study to show that even on closure of mines there is occurrence of post mining induced seismic events. The Kumho mine in Korea, some seismic events were reported and on investigation, seismic events occurring within $1000 \mathrm{~m}$ below the surface were detected with just six weeks of monitoring undertaken.

South Africa Gold mines, on closure the excavated voids started to fill with groundwater and post closure of mine seismicity was observed with high magnitudes of up to 3.4. This was possible with the aid of a well-established seismic monitoring system installed and the events were assessed for identification of zones of vulnerability using MMIS.

The Dannemora iron mine in Sweden, though the mining activity was stopped around two decades ago and was proposed to restart the mining activity, some temporary sensors were placed to assess the seismicity of the area, most events had direct effects on the previous mining activity and some of them caused by re-activation of faults which are already existing.

The monitoring of seismicity should be done through deployment of seismic or microseismic systems. Microseismic monitoring networks are well suited for assessing seismically active areas. When an abandoned old mine is subjected to the gradual degrading of supports and due to the role of various underground geological factors, tectonic forces, water, method of mining etc., there is always a probability of risk lingering with the changing of state of stress within the rockmass. The major points to be considered, when assessing seismicity of a deep hardrock mine are as follows:

1. The installed monitoring system should not only record the largest events but also record the microseismic events, which needs to be quantified and used as precursory warning signal for a forthcoming event of a higher 
magnitude. Thus, the required seismic monitoring system that shall be installed must include the overall monitoring objectives with reference to the purpose of study.

2. To record induced microseismic events, geophone arrays are recommended due to reduced attenuation of ground velocities compared to accelerations, even for small source sensor distances. While uniaxial geophones offer the best return on cost vs. performance, the planar layout, due to the presence of only one mining level, requires the use of at least a few triaxial geophones in order to eliminate the intrinsic symmetry in seismic event location.

3. A three-dimensional representation of recorded events in relation to the geometry of mine workings and the parameters can be quantified. This would be possible, with an advanced monitoring system and well-designed seismic array.

4. For each of the seismic event, it was found that the parameters like inelastic deformations (co-seismic) P and the seismic radiated energy E should be independently estimated. Using these measurements, the apparent stress, apparent volume and drop in energy index can be quantified for each event. On grouping the actual recorded seismic events, they can be analyzed jointly.

5. For better seismic hazard risk assessment, further studies with even smaller time intervals is recommended. Correlations used should be more precise between the depth and seismic parameters, taking into consideration other possible factors affecting seismicity like geological structures and areas with contrasting geomechanical properties.

6. It is found that the choice of technique depends on the duration (short-term or intermediate-term or long-term) of monitoring, the objective required to be met varies on siteto-site basis

There are several methods that may be used to assess seismicity in underground mines. Quite a lot of seismic parameters have been considered and analyzed for site specific relationships to be established at various mines. The type of methods for seismic hazard assessment are waveform and seismic source parameters based, indirect waveform methods - rate of Energy Released (ERR), Excess Shear Stress (ESS), Volume Excess Shear Stress (VESS), Local Energy Release Density (LERD), Coulomb stress change ( $\triangle \mathrm{CFF})$, Cell evaluation method - Modelled Groundwork (MGW), Departure indexing (DI), Modified Mercalli Intensity Scale and Seismic Hazard Scale (SHS).

Based on frequency-magnitude relations in terms of seismic activity rate, $\lambda, b$ value from Gutenberg-Richter and the maximum magnitude, $X_{\max }$, that have occurred during the period (T) of monitoring and based on frequency content analysis. Seismic hazards can also be analyzed, deterministically or probabilistically. Based on the available parameters the method can be chosen for hazard assessment.

\section{Conclusions}

Seismic hazard risk assessment should integrate the effects of all the seismic events occurring at different locations of mining area during mining and post mining, along with their uncertainties also being considered. Based on the recorded data and some of the derived parameters for the previous ten years, an attempt should be made to evaluate the existing hazard. The past records of induced seismicity due to mining should be used as a precursor for identification of the impending future event.

From the studies, it is very clear that on post closure of mines, a dedicated well spread and connected seismic monitoring system needs to be deployed to assess the longterm risks involved to monitor the post mining induced seismicity in Kolar Gold Fields because of the following reasons:

1. The mines have been worked up to a depth of $3200 \mathrm{~m}$ with an unfilled excavation mine void spread over $1500 \mathrm{~km}$. These mine voids are inundated with water up to $400 \mathrm{ft}$ in the shaft locations. This inundation leaves an unstable condition in the underground mines prone to sudden violent rockbursts with increasing or decreasing water table level.

2. The presence and role of the major underground Mysore North Fault (MNF) located between two actively mined out gold bearing veins may be triggered by the inundation and lead to stick-slip failure along the fault plane in case of any scale of rockburst occurrence. This condition if triggered may lead to a major catastrophe.

3. The fragile condition of the subsurface leaves the area prone to instability of the underground mines inducing apprehensions and fears in the people residing above the mining area.

The mining area of Kolar Gold Fields has always been a point discussion as a dump yard for nuclear waste in November 2012, proposed to be converted into a satellite township in November 2018 by government. According to the latest update, the Centre in December 2020 announces to resume gold extraction at Kolar Gold Fields.

With reference to the above future planning at hand, it is essential to deploy a seismic monitoring system back in place to aid in effective mine planning and in post mining land reclamation. The mitigation measures shall help in identification of the potential areas of high hazards, in strengthening the vulnerable areas and relocation of people if required.

\section{Acknowledgements}

The authors are grateful to Dr. H S Venkatesh, Director NIRM for permitting to publish this paper in this Journal. The authors also express their thankfulness to Dr. V R Balasubramaniam, Project Leader, Science and Technology 
research project work in the study area granted by Ministry of Mines, Govt of India. The authors are also thankful to Dr. Sripad R Naik, Head of Department - Numerical Modelling, NIRM for his constant support and guidance in publishing this paper. The authors express their gratitude to the Ministry of Mines, Govt of India for approval and granting fund to support and carry out the Science and Technology research work.

\section{References}

1. Australian Centre for Geomechanics Technical Report (2013): The University of Western Australia. Council for Geoscience: 2013 Annual Report

2. Beck, B.A., and Brady, B.H.G. (2002): Evaluation and application of controlling parameters for seismic events in hard-rock mines. International Journal of Rock Mechanics and Mining Sciences, vol. 39 pp.633-642

3. Beer, W.D. (2000): Seismology for rockburst prediction. Final project of GAP 409, Safety in Mines Research and Advisory Committee, SIMRAC

4. Bolt, B.A. and Abrahamson, N.A. (2003). Estimate of Strong Seismic Ground Motions. In International Handbook of Earthquake and Engineering Seismology, IASPEI, Part B

5. Brown, L.G. (2015): Seismic hazard evaluation using apparent stress ratio for mining-induced seismic events. Master's Dissertation, Department of Engineering, Laurentian University, Sudbury, Ont

6. Brown, L. and Martin, H. (2017): Identifying local stress increase using a relative apparent stress ratio for populations of mining-induced seismic events. Canadian Geotechnical Journal, Vol. 54 No. 1 pp. 128-137

7. Durrheim, R. J., Anderson, R. L., Cichowicz, A., Ebrahim-Trollope, R., Hubert, G., Kijko, A., McGarr, A., Ortlepp, W. D. and van der Merwe N. (2006): The Risks to Miners, Mines and the Public posed by Large Seismic Events in the Gold Mining Districts of South Africa. Proceedings of the Third International Seminar on Deep and High Stress Mining 2-4 October Quebec City, Canada

8. Emilia Nordstrom, Savka Dineva, Erling Nordlund (2017): Source parameters of seismic events potentially associated with damage in block 33/34 of the Kiirunavaara mine (Sweden). Acta Geophys 65:1229-1242

9. Handley, M. F. (2013): Pre-mining stress model for subsurface excavations in Southern Africa. Journal of the Southern African Institute of Mining and
Metallurgy, vol. 113, no.6 pp. 449-471

10. Hedley, D.G. F. (1992): Rockburst handbook for Ontario hardrock mines. CANMET Special Report SP92-1E p.305

11. Hudyma, M.R. (2004): Mining-induced seismicity in underground, mechanised, hardrock mines-results of a World Wide Survey. Australian Centre for Geomechanics, Research Report, Perth

12. Hudyma, M. R. (2008): Analysis and Interpretation of Clusters of Seismic Events in Mines. Doctoral Dissertation, University of Western Australia

13. Joanna Holmgren, (2015): Induced Seismicity in the Dannemora Mine, Sweden. Department of Earth Sciences, Uppsala University, Published at Department of Earth Sciences, Uppsala

14. Kijko, A., and Funk, C.W. (1994): The Assessment of seismic hazards in mines. Journal of the South African Institute of Mining and Metallurgy, July pp. 179-185

15. Kijko, A., (1997): Keynote lecture: Seismic hazard assessment in mines. In Proc. 4th Int. Symp. On Rockbursts and Seismicity in Mines (eds. Gibowicz, S.J. and Lasocki, S.), Balkema, Rotterdam pp. 247-256

16. Krishnamurthy, R., and Srinivasan, C. (1980): Current seismic studies for the detection of rockbursts in Kolar Gold Fields. Indo-German Workshop on Rock Mechanics, NGRI, Hyderabad

17. Lasocki, S. (2005): Probabilistic Analysis of Seismic hazard posed by mining induced events. RaSiM6 Controlling Seismic Risks: proceedings of Sixth International Symposium of Rockburst and Seismicity in Mines, ed. Potvin Y and Hudyma M, pp.151-156

18. Lasocki, S. (2008): Some unique statistical properties of the seismic process in mines. Proceedings of the 1st Southern Hemisphere International Rock Mechanics Symposium, (Editors: Potvin Y, Carter J, Dyskin A, and Jeffrey R) Perth, Australian Centre for Geomechanics, Vol. 1 pp. 667-678

19. Malliga, S. (2013): Source Location of Rock Burst in the Mines of Kolar Gold Fields. International Journal of Science and Research (IJSR) ISSN (Online): 2319-7064

20. Malovichko, D.A. (2017): Assessment and testing of seismic hazard for planned mining sequences. Deep Mining 2017: Eighth International Conference on Deep and High Stress Mining - Wesseloo J (ed.) Australian Centre for Geomechanics, Perth, ISBN 9780-9924810-6-3

21. Martyna Szydlowska, (2016): Systematic review of 
Georisk in underground hard rock mines. Master's Dissertation, European Mining, Minerals and Environmental Program, Aalto University

22. Mendecki, A.J., van Aswegwn, G., and Mountfort, P. (1999): A guide to routine seismic monitoring in mines. A Handbook on Rock Engineering Practice for Tabular Hard Rock Mines, edited by Jager A J and Ryder J A, Chap. 9, pp. 287-309, The Safety in Mines Research Advisory Committee, Johannesburg.

23. Mendecki, A.J., Lnch, R.A. and Malovichko, D. A. (2010): Routine Microseismic Monitoring in Mines. Proceedings of the Australian Earthquake Engineering Society 2010 Conference Perth, Western Australia Institute of Mine Seismology pp. 1-33

24. Mitri, H.S., Tang, B., and Simon, R., (1999): Finite Element modelling of mining induced energy release and storage rates. The Journal of The South African Institute of Mining and Metallurgy, vol.99, no.2 pp.103-110

25. Orlecka-Sikora, B., Papadimitriou, E.E. and Kwiatek, G. (2009): A study of the interaction among mininginduced seismic events in the Legnica -Glogow Copper district, Poland. Acta Geophysica, vol.57, no. 2 pp.413-434

26. Panduranga, R., Dharuman, R., Purusottaman, D. and Mishra, A.K. (2009): A Report on Geotechnical Evaluation of Rockburst Hazard in BGML area, Kolar Gold Fields, Kolar District, Karnataka (FS 2005-07)

27. Poplawski, F.P. (1997): Seismicity underground with particular reference to rockburst problems at Mt. Charlotte mine. Doctoral Dissertation, The University of Melbourne, Melbourne, pp. 319

28. Praveena Das J., Balasubramaniam V.R., Goverdhan Kantepudi, Ganapathy G.P., (2016): Overview of seismic monitoring and assessment of seismic hazard based on a decade of seismic events. Published by Atlantis Press, ISBN: 978-94-6252-260-2, ISSN: 23525401

29. Raju, N.M., Jha P.C., Srinivasan, C et al.., (1991): Combating the problems of rockburst at Kolar Gold Fields. Journal of Mines, Metals and Fuels, Vol XXX, No.11-12 pp. 370-376

30. Ryder, J.A. (1988): Excess shear stress in the assessment of geologically hazardous situations. $J$ South African Inst Min Metall 88, 27-39

31. Sarfraz, Ali (2016): Evaluation of flooding induced mining seismicity with a view to characterize safety margins for surface structures under existing and flooded conditions in the Central Rand, Johannesburg. Doctoral Dissertation, the Faculty of Engineering and the Built Environment, University of the Witwatersrand, Johannesburg

32. Shen, B., Luo, X., Moodie, A., and McKay, G., (2013): Monitoring longwall weighting at Austar Mine using microseismic systems and stressmeters. Proceedings of the thirteenth Coal Operators' Conference, University ofWollongong, The Australasian Institute of Mining and Metallurgy and Mine Managers Association of Australia, pp. 50-59

33. Spottiswoode, S.M. (1990): Volume excess shear stress and commutative seismic moments. In: Fairhurst C (Editor) Rockbursts and Seismicity in Mines, Balkema, Rotterdam, 39-49. ISSN 0148-9062

34. Srinivasan, C., Willy, Y.A., and Carter, R.M. (2013): Characteristics of Rockbursts in the flooded mines of Kolar Gold Fields. 8th International conference of Rockbursts and Seismicity in mines, Moscow, Russia

35. Synapse Science Center (2006): Seismic activity at abandoned mines

36. Uday Singh, Melinda Henderson and Marty Hudyma (2002): Seismic Hazard Assessment at Junction Gold Mine. Conference Paper

37. van Aswegen, G., and Bulter, A.G. (1993): Application of quantitative seismology in mines. $3^{\text {rd }}$ Symposium on Rockburst and Seismicity in Mines, Kingston, Ontario

38. van Aswegen, G. (2005): Routine seismic hazard assessment in some South African mines. In Proc. 6th Int. Symp. on Rockbursts and Seismicity in Mines: Controlling Seismic Risk (eds. Potvin Y and Hudyma M), Australian Centre for Geomechanics, Perth pp. 437-444

39. Srinivasan,Vinoth (2015): Microseismic studies for slope stability monitoring in an Indian opencast coal mine. Doctoral Dissertation, faculty of science and humanities, Anna University, Chennai

40. Wiles, T.D. (1998): Correlation between Local Energy Release Density and Observed Bursting Conditions at Creighton Mine. Mine Modelling Pty Ltd report, Mt Eliza, Australia, 3930

41. Woodward, K. (2015): Identification and delineation of mining induced seismic responses. Doctoral Dissertation, the University of Western Australia, Perth. 